sage from $B$, he can foretell accurately that this particular atom will decay in exactly one minute as well as that he himself is unable to change his mind. It is easier firmly and unambiguously to disbelieve in tachyons. This is my own policy.

$$
\text { Yours faithfully, }
$$

$$
\text { J. H. Fremlin }
$$

Department of Physies,

University of Birmingham.

1 Thouless, D. J., Nature, 224, 506 (1969).

\section{Quare Multiplicandum Est}

SrR,-There is an oft-repeated myth that the development of mathematics was held up by the cumbersome system of Roman numerals. In fact, Roman multiplication is easy and does not require the use of multiplication tables. The system can be used on an abacus or written out, as the following simple example will show.

To multiply $96 \times 16$.

\begin{tabular}{|c|c|c|c|c|c|c|c|}
\hline M & D & $\begin{array}{l}\mathrm{C} \\
+\end{array}$ & $\mathbf{L}$ & $\mathrm{x}$ & $\begin{array}{l}\mathrm{V} \\
+\end{array}$ & $\stackrel{\text { I }}{+}$ & \\
\hline & + & + & - & $\begin{array}{l}- \\
+ \\
+\end{array}$ & $\begin{array}{l}+ \\
+ \\
+\end{array}$ & + & $\begin{array}{l}=\times \mathrm{I} \\
=\times \mathrm{V} \\
=(\text { alt } . \times \text { alt. })\end{array}$ \\
\hline+ & & - & + & + & & & $=\times \mathbf{X}$ \\
\hline+ & + & & & ++ & + & + & \\
\hline
\end{tabular}

To multiply XCVI by XVI.

Total $=$

$+1$

$$
++++
$$

It will be seen that using the multiplier a digit at a time we simply move the whole "plus-and-minus pattern" (here plus, space, minus, plus, plus) the requisite number of steps to the left. In addition, when multiplying an alternate digit by itself (the alternates are every second one, $\mathrm{V}, \mathrm{L}, \mathrm{D}$, etc.) we must write the answer in its place and then repeat it once below and once to the right as in the third line above.

Had we been multiplying by 14 instead of 16 our first row would have been a multiplication by minus one instead of plus one, so we would have reversed all the signs in the pattern while keeping them in their correct places.

$$
\text { Yours faithfully, }
$$

\section{MARGARET LAZARIDES}

Yeolmbridge House,

Near Launceston,

Cornwall.

\section{Unfair to W's}

Sin,-Concerning the article "Can Scientists afford Science?" (Nature, 226, 10; 1970), what price the definition of a Publishing Scientist? The Royal Society used to, and the Journal of Physiology still does, list joint authors of a paper in alphabetical order. Both journals qualify for inclusion in Current Contents. I write with feeling. Yours faithfully,

$$
\text { R. A. Weate }
$$

Institute of Ophthalmology,

University of London,

Judd Street, London WC1.

\section{University News}

Dr C. E. Johnson, AERE, has been appointed professor of experimental physics in the University of Liverpool. The following appointments have been made in the University of London: Professor C. H. Barnett to the chair of anatomy tenable at St Thomas's Hospital Medical School; Professor J. D. Smyth to the chair of parasitology tenable at Imperial College of Science and Technology; Dr A. M. James to the chair of physical chemistry tenable at Bedford College.

\section{International Meetings}

July 18-23, 1971, Molecular Energy Transfer, Cambridge (Dr A. B. Callear, Department of Physical Chemistry, University of Cambridge, Lensfield, Cambridge).

\section{Sabbatical Itinerants}

In the hope of providing some practical assistance in the good cause of mobility between laboratories, Nature advertises the needs for housing of families about to take up periods of sabbatical leave. To begin with, no charge will be made for advertisements like this. It is hoped that a period of experiment will show what form these advertisements could most usefully take and whether they are effective.

Wanted: Furnished flat in London, reasonable commuting distance from Imperial College, for visiting professor and wife, June 15 to August 31, 1970. Please contact Dr D. A. Walker, Botany Department, Imperial College, London SW7.

Wanted: Furnished house or flat with $3 / 4$ bedrooms in London, preferably north, for 1--2 months from late June 1970. Please contact Mr or Mrs T. L. Hutchings, "Two Trees", Hernes Road, Oxford OX2 7PT (telephone Oxford 55601).

Wanted: Furnished 2 or, preferably, 3-bedroomed flat or house in North London for Canadian professor with teenage children. Central or other good heating, accessibility to tube, required. Threebedroomed house in Winnipeg available in exchange. Please contact Dr Peter E. Dresel, 681 Cordova Street, Winnipeg 9, Manitoba, Canada.

Wanted: American scientist, wife, and children aged $12,11,8$ and 7 , wish to exchange 4 or 5 bedroom house or flat within easy reach of Holborn for 5-bedroom house in New Jersey, 20 minutes to midtown New York City. Approximately June 15 to end of July. Car swap possible. Please contact Professor G. F. Elliott, 28 Tylney Avenue, London SE19 (telephone 01-670 0141).

Wanted: Furnished house or apartment ( 2 bedrooms, central heating) for American university professor, wife, and son aged 4, in London or suburbs (convenient transport to British Museum, Natural History) from September 1, 1970, to March 1, 1971. Please contact Dr K. F. Liem, Department of Anatomy, University of Illinois Medical Center, Chicago, Illinois 60612, USA.

Wanted: To rent from July 1970 to August 1971. Furnished house or apartment, 3 or 4 bedrooms, central heating, in central London, preferably Kensington or Chelsea. Will also consider an exchange for 3 bedroom, 3 bath spacious house in Philadelphia suburb. Please contact Dr L. Warren, 433 Bryn Mawr Avenue, Bala Cynwyd, Pennsylvania 19004, USA.

Vacant: From late July to late September, 4-bed. roomed, furnished house in north London about 40 minutes from central London. Please contact Dr John Tooze, Imperial Cancer Research Fund, Lincoln's Inn Fields, London WC2.

Vacant: 3-bedroomed, centrally heated house with garage and garden in Bearsden, Glasgow, from September 1970 to September 1971. Please contact Dr I. R. Pendleton, Microbiology Department, University of Glasgow W2. 